\title{
Med school to relax rules on business links?
}

Boston

A report by senior faculty members at Harvard Medical School has recommended easing conflict-of-interest guidelines to give researchers greater flexibility in their commercial dealings and more opportunity to profit from their work.

The proposals are said to reflect concern that researchers are leaving for institutions with less stringent rules on stockholding in outside companies and earnings from consultancy fees.

Under the medical school's current guidelines, which were set in 1990 and modified in 1993, faculty members cannot own more than $\$ 20,000$ of stock in companies for which they do research. Furthermore, consulting fees from an individual company cannot exceed $\$ 10,000$ per year.

In addition, researchers cannot spend more than 20 per cent of their time working outside the university. Nor can they enlist students or postdoctoral fellows in their corporate activities.

The new guidelines are said to bring the monetary limits into line with those at other leading universities. "The current limits on equity ownership and consulting are quite low by contemporary standards," says David Blumenthal, a physician and health-policy specialist at the medical school and Massachusetts General Hospital. "It's appropriate that they be increased."

Even with the revamped policy, he notes, "Harvard will not be more permissive than other places like Stanford and Johns Hopkins". John Lacey, a spokesperson for the medical school, says that it has "some of the most stringent guidelines in the country", adding that "researchers are going to other institutions because they have more relaxed guidelines".

But Jonathan Beckwith, a microbiologist at the medical school, doubts this, saying it may just be an excuse to relax the guidelines. "This place is growing like mad. We're attracting stars from all over the world, and I haven't heard of any cases of people leaving."

Sheldon Krimsky, a health-policy specialist at nearby Tufts University, agrees. "Given how hard it is to get an appointment there, it's hard to believe that many people would give up a Harvard job for the freedom to pursue business ventures. It's even harder to believe that Harvard is worried about people leaving, because they have their pick."

The medical school faculty is split over the issue, according to one senior researcher who declines to be identified. "There's a real division of opinion here," he says. "Where you come down depends on what personal interests you have at stake. Those most in favour of the new policy want a bigger

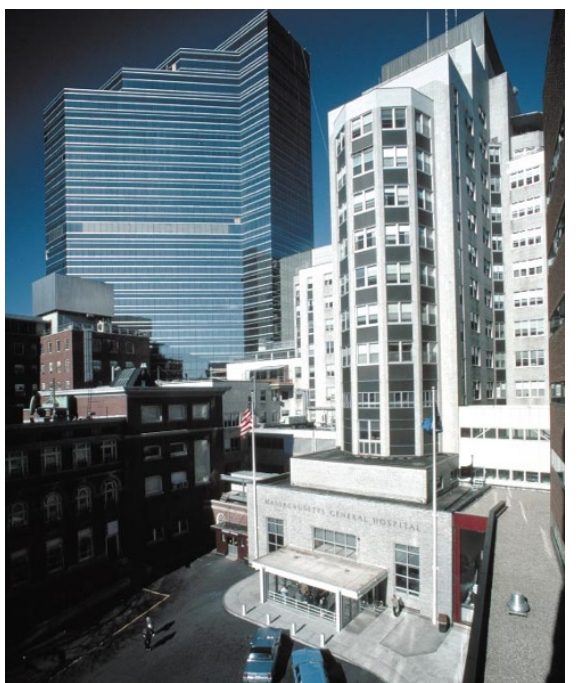

Massachusetts General Hospital: tight guidelines may be causing the loss of top researchers.

financial return for the work they do for companies."

Krimsky, who attended a meeting at Harvard last month where the revised guidelines were discussed, argues that any steps to ease conflict-of-interest rules are worrisome "because we're already seeing some bad effects". He says that scientists are becoming more secretive, impeding exchange of information or cell lines, and that publication is being delayed to protect proprietary concerns (see Nature 398, 359; 1999).

"There are already many problems, and the proposed changes would just exacerbate them," he says. "Harvard should set the highest standards for ethics in research, since they set the highest standards when it comes to offering positions to their faculty."

Hank Greely, a law professor at Stanford University and co-director of its Program in Genomics, Ethics and Society, says that it is healthy for institutions like Harvard to review their ethics policies regularly, but that a perfect solution is impossible. "As long as there are interactions between commercial sectors and academia, you have to worry about conflicts of interest. But breaking off these interactions would be bad for society."

Nevertheless, the unnamed researcher worries that the lure of money can divert universities from their primary mission - "getting the truth". This, he says, is especially true at an institution such as Harvard, whose motto is simply Veritas.

The report, drafted by a panel headed by Eugene Braunwald, professor of medicine and of ambulatory care and prevention at the medical school, is not being made public. But officials say that its recommendations will receive further consideration from the school's faculty and administrators before they are adopted.

Steve Nadis

\section{Spanish boost for young scientists}

\section{Barcelona}

The Spanish government, sensitive to criticism over the difficulties of providing attractive career opportunities for young researchers, has approved a programme to improve the pay and working conditions of university assistant professors.

The programme, which came into effect last month, removes a limitation preventing universities from employing full-time assistant professors for more than three years. They can now have their contracts renewed as many times as necessary if they pass an external evaluation.

In addition, new recruitment procedures have been introduced for full-time assistant professors with $\mathrm{PhDs}$, who will receive the same salary - 4 million Ptas (US\$23,700) a year - as associate tenured professors.

The move is expected to benefit more than 10,000 assistant professors and to cost the government 21 billion Ptas over three years. Autonomous regional governments will have to contribute a further 7.7 billion Ptas over this period.

The government's actions have been welcomed by labour unions representing university researchers. But left-wing parties and some university rectors are concerned at the financial implications and the lack of medium- and long-term provisions. Some observers argue that the award of the extra money may be politically motivated, as a general election is due to take place next month.

Antonio Caparrós, rector of the University of Barcelona, says that the government's action are likely to stabilize the position of assistant professors. But he cautions that problems involving university professors require long-term solutions.

Meanwhile, Jorge Fernández-Díaz, Spain's secretary for education, has promised to deliver a set of university reforms to parliament by the end of the year. These are expected to include a proposal to reduce from two to one the number of local university representatives on five-member appointment committees - a controversial aspect of Spain's recruitment procedures (see Nature 396, 712; 1998). Xavier Bosch 